Research Article

Open Access

Natalia Kharchenko

\title{
Problem of Understanding in the Psychology Science Studies of Ukrainian and Russian Researchers
}

DOI 10.1515/ sigtem-2016-0005

\begin{abstract}
The article discusses the phenomenon 'understanding' from the position of psychological science. The paper also examines the relationship between the categories of 'understanding', 'knowledge', 'perception', 'sense', in particular the relationship (interdependence) in dyads 'understanding-knowledge', 'understandingperception', 'understanding-sense'. The article also covers the functions of understanding (cognitive, regulatory, ideological), levels of understanding (depth, clarity and completeness), forms of understanding (understandingrecognition, understanding-hypothesis (prediction), understanding-unification), stages of understanding (preunderstanding, a vague understanding, insufficiently clear understanding, a clear understanding, a complete understanding), types of understanding (natural, cultural, creative). The analysis of scientific literature made it possible to draw conclusions that understanding is a complex and multidimensional phenomenon, which can act as a natural and social, conscious and unconscious, objective and subjective, as the process and as the result. Understanding as a psychological phenomenon covers all mental processes: thinking, memory, representation, creative imagination, emotional and volitional processes, properties and abilities of the individual and pervades and mediates cognitive procedures (observation, description, prediction, explanation, etc.). Understanding is the target process, motivated, active, emotional and volitional, productive and individually personal.
\end{abstract}

Keywords: understanding, thinking, perception, meaning, knowledge, apperception (experience).

'The ability to understand the reality, natural and social, to understand other people and himself, culture texts this ability underlies human existence' (A. A. Brudnyi, 1998).

\section{Introduction}

The problem of understanding is reflected in the studies of both Ukrainian and Russian scientists and psychologists (V. A. Artemov (Артемов, 1954), V.P. Belyanin (Белянин, 2001, 2004), L.G. Vasil'ev (Васильев, 1991), А. A. Brudnyi (Брудный, 2005), L. P. Doblayev (Доблаев, 1982), А. I. Zimniaya (Зимняя, 2001), А. А. Zalevskaja (Залевская, 2005), V. P. Zinchenko (Зинченко, 2012), V. V. Znakov (Знаков, 1986, 2005, 2008), H. S. Kostyuk (Костюк, 1988), А. A. Leontiev (Леонтьев, 1999), A. R. Luria (Лурия, 2002), S. L. Rubinstein (Рубинштейн, 1976), L. A. Selitskaya (Селицкая, 1976), А. А. Smirnov (Смирнов, 1966), A. N. Sokolov (Соколов 1968), N. V. Chepeleva (Чепелева, 1990) and others).

Their attention was focused on different characteristics of understanding: the possibility of depth and fullness of understanding, forms of leakage, levels, stages, types; factors affecting the successful under-

*Corresponding author: Natalia Kharchenko: Pereyaslav-Khmelnytskyi State Pedagogical University named after Hryhoriy Skovoroda, Ukraine, E-mail: harchenk0123@rambler.ru, psycholing.elab@gmail.com 
standing; typology of understanding; modelling of the processes of understanding; dynamics of scientific approaches to the studied phenomenon; the main lines of investigation of understanding in Western psychology, etc. At the present stage of psychological science, development become actual topical issues of 'studying comprehension strategies as a process and causing this process mechanisms and operations' (Залевская, 2005, 271), and also 'interpretation of the phenomenon of understanding from the perspective of human existence' (Знаков, 2005, 8). Scientists agree that understanding is extremely complex and multifaceted phenomenon, about which little is known and which is impossible to give a general and comprehensive definition. 'It's easier to solve understood than understanding', - says V. P. Zinchenko (Зинченко, 1998, 98).

\section{The Aim of the Study}

To research the lexical interpretations of this phenomenon - understanding.

\section{Materials and Methods}

The analysis and synthesis of psychological and psycholinguistic literature is used in this article.

In dictionaries (Толковый словарь живого великорусского языка, 1956; Толковый словарь русского языка, 2000), the term 'understand' ('realise') is defined as to understand something, to comprehend in mind, to learn, to understand, enlighten, embrace by sense, reason, to find the meaning in something, to see the cause and consequences; penetration into someone else's thoughts, state, feelings.

In Concise Dictionary of Cognitive Terms, 'understanding' is defined as a cognitive activity, the result of which is to establish the meaning of the text (Краткий словарь когнитивных терминов, 1996). We find some approaches in the big dictionary of psychology to study this phenomenon, in particular:

1. The individual's ability to conceptualise, comprehend the content, sense, meaning of something.

2. Cognitive process of comprehension of content, meaning.

3. The product of the process of understanding - the very interpretation of something (text, behaviour, dreams, etc.).

4. Understanding as one of the goals of knowledge and learning (Большой психологический словарь, 2004).

\section{Results}

In psychology, there have been outlined two approaches to the study of understanding: the first understanding as the process, the second - the understanding as a result of this process.

So, S. L. Rubinstein (Рубинштейн) drew attention to the procedural nature of understanding. He argued that 'understanding as the process, as mental thought activity is the differentiation, analysis of things, phenomena in the relevant to the context qualities and implementation of connections (synthesis) that make up this context' (Generalization and abstraction in the process). 'Understanding, - he says, - is the specific process' (Рубинштейн, 1976, 236-237). The essential feature of this process, according to S. L. Rubinstein, is that 'it is always the transition from misunderstanding to understanding. It is achieved by inserting the object of understanding in all new connections, which form it' (ibid).

In the view of A. I. Zimniaya (Зимняя), the process of opening the semantic connections and relationships between concepts is called comprehension and the result of it - understanding or misunderstanding. Understanding (misunderstanding), she continues, lies in the quality of the result of the process of reflection as well as the reflection itself is included integrally into the process of semantic perception of verbal communication, presenting its internal productive side (Зимняя, 2001).

G. I. Bogin (Богин) differentiates the substantial and procedural sides of understanding. The substantial aspect of understanding is characterised by a person's ability to understand. Procedural consists of a 
set of actions and procedures, which provide the transition from misunderstanding to understanding. At the same time, the scientist focuses on the fact that '... the true culture of understanding provides strong enough development of substantial and procedural sources in understanding' (Богин, 2001).

It should be noted that for many scientists (A. A. Brudnyi (Брудный, 2005), L. G. Vasil'ev (Васильев, 1991), V. V. Znakov (Знаков, 2005, 2008), H. S. Kostyuk (Костюк, 1988), А. A. Leontiev (Леонтьев, 1999), etc.), the problem of 'strict' differentiation of understanding on the process and the result did not exist.

So, H. S. Kostyuk (Костюк), in his famous work 'On the psychology of understanding', focused attention on various aspects of this complex phenomenon, reflecting the different meanings of the word 'understanding', namely understanding as a person's ability to understand something, that is the process of understanding, i. e. the insight into the various objects, the state of consciousness of the person, revealing the essence of the problem; understanding as a result of this process, which is expressed in the judgements, conclusions, concepts, attitudes, which are formed at the individual as a result of his/her understanding of the certain objects (Костюк, 1988, 197).

The scientist reveal the main characteristics of the process of understanding: aim direction (the understanding purports to disclose connections in some phenomena of objective reality, find obscure, to answer a question and solve a certain problem), motivation (the driving force of understanding), activity (analytical-synthetic activity), productivity (images, ideas, opinions, concepts as a result of understanding), emotions (experience, feelings - satisfaction, dissatisfaction, doubt, confidence, surprise, complexity of the problem, the possibility of its resolution, etc. - that arise as a result of understanding); the role of sensory images, willpower, as well as the individual characteristics of the person in the process of understanding (Костюк, 1988].

Considering the two sides of understanding (process and result), H. S. Kostyuk concludes that they are closely linked. Understanding occurs there, said the scientist, where there is the ability of the living creatures to understand something, which [ability] is expressed in the process of understanding. During this process, changes the state of consciousness of the person due to the fact that it becomes clear what was previously incomprehensible. Understanding is expressed in the concrete results (judgements, concepts, etc.), which can be judged on its availability or truth (ibid).

A. A. Brudnyi notes that '... the understanding exists as the process and, as the experienced by the individual and its result’ (Брудный, 2005, 132).

According to A. A. Leontiev (Леонтьев 1999), between the process of understanding and its result, it is impossible to draw a clear line. The scientist introduces the concept of the 'image of the text content' not as a total or final result of understanding, but understanding of the process, taken from its content side. Image of the content of the text, according to the scientist, is fundamentally dynamic. It is not, and it becomes, and only in constant formation is its being' (Леонтьев, 1999, 142).

This view is shared by A. P. Tupitskaya who defines understanding as the 'resulting process that accompanies a receptive activity' (Tupitskaya, 1995, 58).

Many psychologists (A. Yu. Agafonov (Агафонов, 2003), А. A. Brudnyi (Брудный, 2005), V. V. Znakov (Знаков, 2005, 2008), А. В. Kovalenko (Коваленко, 1999), А. A. Smirnov (Смирнов, 1987), N. V. Chepelieva (Чепелева, 1990) etc.), while exploring the place of understanding in human mental activity, associate it with mental activity. Understanding, according to the scientists -, is the original phenomenon of thinking. Man begins to think, noted A. A. Brudnyi, when he has the need to understand something. In this connection, it is interesting, that A. Yu. Agafonov writes: 'without understanding the thinking is impossible, but - continued the scientist - when we affirm it we mean that understanding which is itself ... the result of actually thinking, and ignore the procedural nature of the understanding, and the thought process is not possible without dynamics (italics by the author of article) of understanding (Agafonov, 2003, 232). We subscribe to the statement of a psychologist that 'understanding as a result of thinking should be distinguished from the dynamics of understanding. Thinking as a process of understanding, and thought, as a result of understanding reflect different - procedural and rezultative - aspects of consciousness in the thinking aspect' (Agafonov, 2003, 261).

V. V. Znakov, in his work, argues that the main effort in psychological science should be focused on procedural, dynamic aspects of the understanding. 'It is this line of researches', he writes, 'seems to us a 
promising and requiring the urgent solutions' (Знаков, 1986, 169-170). Results of many years' research of the scientist led him to make conclusions that understanding is not an independent mental process, such as attention, memory, etc. It is the result of thinking, but at the same time it is one of its processes (ibid).

L. P. Doblayev (Доблаев, 1982) differentiates understanding in a broad and narrow sense. Understanding, in a broad sense, is the establishment of significant connections and relationships between the objects of reality through the use of the hidden (unexpressed) knowledge. In this regard, it is a manifestation of different cognitive processes such as meaningful perception or recognition, memorisation or reflection, imagination or thinking.

In the narrow sense, understanding is a component of thinking, which consists in identifying and disclosing of hidden (unexpressed) issues in a problem situation on the basis of existing knowledge and the use of special techniques (Доблаев, 1982).

Most researchers (Yu. A. Agafonov, A. A. Zalevskaya, A. I. Zimniaya, A. A. Smirnov, N. A. Rubakin etc.) emphasise that understanding is not limited only by thinking and is a phenomenon that includes other cognitive processes - memory, speech, representation (imagination). Essence of understanding, says Yu. A. Agafonov, is also expressed in the phenomena of perception, representation, emotional experience and reflexion (Agafonov, 2003, 232).

We share the views of A. A. Zalevskaya (Залевская, 2005), A. R. Luria (Лурия, 2002), I. M. Rumyantseva (Румянцева, 2004) and L. A. Selitskaya (Селицкая, 1976), according to which understanding is a complex, integrated 'perceptual-cognitive-affective' (Залевская, 2005) process, which includes thinking, memory, representation, reproductive and creative imagination, emotional and volitional processes, peculiarities and abilities of the individual, as well as 'pervades and mediates all other cognitive procedures (observation, description, prediction, explanation, etc.)'.

The scientists (Yu. A. Agafonov, A. A. Brudnyi, L. P. Doblayev, V. V. Znakov, A. K. Tikhomirov and others) repeatedly raised the issue of the relationship between categories of 'understanding', 'knowledge', 'cognition', in particular, the relationship (interdependence) in dyads 'understanding-knowledge', 'understanding-cognition'. Thus, it was proved that understanding is always based on the knowledge gained in both the current and previous mental activity. In turn, any knowledge contains the potential possibilities of its understanding (Знаков, 2005, 6).

L. A. Selitskaya considers understanding as meta-knowledge, assuring that it does not exist outside of knowledge and is a form of knowledge (Селицкая, 1976). A. A. Brudnyi writes: 'Understand - means to gain knowledge'. Cognitive function of understanding consist in gaining of some knowledge about reality and applying it; as a result of understanding, the knowledge becomes a part of the inner world of the individual and affects the regulation of its activity' (Брудный, 2005, 24).

Understanding is different from knowledge; in particular, it is a reflection of knowledge and action with it (Знаков, 2008, 6). A person understands not knowledge, but the objective world displayed in it. Knowledge is not the purpose of understanding, but a means of it (Знаков, 2008, 20).

Understanding, according to scientists, is a prerequisite for learning, forming a coherent picture of the world of scientific notions about the object of knowledge. The function of understanding in learning consists in realising, analysing of knowledge, having to subject a problem character. The process of cognition is primary in relation to the process of understanding. However, assures V. V. Znakov, it is impossible to distinguish these concepts (Знаков, 2008).

Scientists closely associate the phenomenon of 'understanding' with the concept of 'meaning'. Modern research in the field of psycholinguistics (A. A. Leontiev, V. P. Belyanin, N. V. Chepeleva etc.) pay attention to such psychological terms as meaning, comprehension, semantic field, and semantic links. V. P. Belyanin says 'Understanding is a deciphering of the general sense, which stands directly behind the perceived speech stream; it is the process of converting speech into meaning that stands for it' (Belyanin, 2001, 59).

According to V. V. Znakov, understanding as one of the components of knowledge is connected not so much with the procedures of mastery by subject of understanding of a new knowledge as to the procedure of his thinking, sense-formation, ascribing meaning to the new knowledge gained in the process of mental activity. To understand, says the scientist, means to grasp the sense (meaning) of understood (Знаков, 
2005 , 26). Sense as an ideal thinking model is constructed by the subject in the process of understanding (Kolodina, 2001).

Studying the phenomenon of understanding, the scientists (V. A. Artemov, A. A. Zalevskaya, A. I. Zimniaya, V. V. Krasnyh, E. S. Kubryakova etc.) note the importance of the previous experience (apperception) of the recipient, 'the individual cognitive space' (terminology of V. V. Krasnyh). Apperception, in their opinion, is the most evident in understanding, which is caused by many factors: knowledge of the language, the object referred to, the practice of hearing, the general level of culture, education, age of the recipient, etc. All these factors influence the process of 'perception-understanding' and define it.

A. A. Brudnyi researched understanding in terms of functions it can perform: cognitive, regulatory and ideological. Cognitive function consists in separating the organisation of knowledge into the system. Regulatory - in predicting the consequences of their actions on the basis of communicative experience with people, knowledge of the rules and norms of behaviour. Ideological - in generating belief (Брудный, 2005).

From the viewpoint of understanding productivity, A. A. Smirnov identified and described its levels, such as depth, clarity and completeness (Смирнов, 1966). Depth of understanding is characterised by how deep and detailed the recipient analyses substantial connections and relationship of situation that is needed to understand. Depth of understanding is related to the phenomenon, which has a deep meaning (laws, regulations, aphorisms etc.). Depth depends on motivation, desire or reluctance of the listener to understand deeply.

Clarity of understanding is the degree of understanding the properties, ties and relations of the object of perception. Lack of clear understanding is called vague, dim or diffuse.

Fullness of understanding is manifested in a number of interpretation variants of the understood facts, in recognising by the person that the concept can be incorporated into different contexts. Depending on the completeness, we can speak about the complete lack of understanding, partial understanding and a complete misunderstanding.

Considering the understanding as a component of thinking, V. V. Znakov points out three of its forms: understanding-recognition, understanding-hypothesis (prediction) and understanding-unification. Depending on the matters in which objective circumstances that require understanding gets a man and what task he/she decides in these circumstances all depend upon the form of understanding arising in the subject (Знаков, 2008, 33). So, understanding-recognition occurs in a situation when it is necessary to answer the question: 'What is it?'. Understanding-hypothesis arises when the man realises the reasons that cause a particular event, and the consequences to which it may lead. By this, the main content of mental activity of the subject, which tries to understand, makes the intelligent actions of prediction. Understanding-unification arises in situations when it is necessary to assemble mentally all components and combine them into the one whole.

In the opinion of A. A. Smirnov, understanding is a complex process that involves several steps (from the point of view of its clarity):

1. Pre-understanding (an allusion to understanding, the emergence of understanding).

2. Dim understanding (understanding is already there, but it is still in an uncertain form).

3. Insufficient clear understanding (a subject still can not express in words the meaning of perceived).

4. A clear understanding (the recipient is able to express the perceived, but reproductively).

5. Full understanding ('liberation from constraint verbal formulation') (Смирнов, 1966, 168-169).

V. P. Zinchenko describes the main types of understanding: natural, cultural, creative (Зинченко, 2012).

Natural understanding involves extracting meaning from the situation. Natural does not mean innate.

This kind of understanding is also preceded by the experience, but it is usually hidden from external observation.

Cultural understanding involves along with extracting meaning from the situation its sign shaping, signification and the opportunity for transmission. Its completeness and adequacy are certified not so much by the behaviour and action as the message, text which should match the original - an object of understanding.

Creative understanding suggests, along with the extracting, signification and sense transmission, the production and shaping of a new meaning. Creative understanding, according to the scientist, is characterised by the deployment of a new counter process of understanding by the addressee-recipient. 
V. P. Zinchenko focuses on the fact that the allocation of three types of understanding is very conditional. They are interrelated. Cultural understanding is not just supply natural one; it overcomes him, opens the new objective relationship and otherwise displays the meaning of previously allocated. Likewise, the creative understanding overcomes natural and cultural understanding (Зинченко, 2012, 191-206).

\section{Conclusions}

The author considers understanding as a complex 'perceptual-cognitive-affective process' (A. A. Zalevskaja (Залевская, 2005)), which consists in separation, perception and comprehension by 'the subject of understanding' (V. V. Znakov (Знаков, 2005, 2008)) of the sense of reality, requiring understanding, its further comprehension and rethinking, resulting in a new generation of meaning, or the deployment of a new counter-process of understanding by the addressee recipient in terms of availability in his previous experience of the necessary linguistic and encyclopaedic knowledge.

Understanding is a complex and multidimensional phenomenon that can act as a natural and social, conscious and unconscious, objective and subjective, both as a process and the result.

Understanding as a psychological phenomenon covers all mental processes: thinking, memory, representation, creative imagination, emotional and volitional processes, properties and abilities of the individual, pervades and mediates cognitive procedures (observation, description, prediction, explanation etc.).

Understanding is the target, motivated, active, emotional and volitional, productive, and individually personal process.

\section{References}

Агафонов, А.Ю. (2003). Основы смысловой теории сознания [Bases of semantic theory of consciousness]. Спб.: Издательство “Речь". (in Russian)

Белянин, В.П. (2001). Введение в психолингвистику [Introduction into psycholinguistics]. М.: ЧеPo.(in Russian)

Белянин, В.П. (2004). Психолингвистика [Psycholinguistics]. М.: Флинта.(in Russian)

Богин, Г. И. (2001). Обретение способности понимать: Введение в филологическую герменевтику [Gaining the ability to understand: Introduction to philological hermeneutics]. Retrieved 12.12.2013. from http://www.bim-bad.ru/docs/bogin_ ponimanije.pdf (in Russian)

Большой психологический словарь (2004). [The big dictionary psychology. Compillers: Mescheryakov, B. Zinchenko, V.]. Сост. Б. Мещеряков, В. Зинченко. Retrieved 12.12.2013. from http://vocabulary.ru/dictionary/30/word/ponimanie. (in Russian)

Брудный, А. А. (2005). Психологическая герменевтика [Psychological germenenvtics]. Москва: Лабиринт. (in Russian)

Васильев Л.Г. Текст и его понимание [Text and its understanding]. - Тверь: ТГУ, 1991. - 171 с.(in Russian)

Даль, В. И. (1956). Толковый словарь живого великорусского языка [Explanatory dictionary of Russian language], Toм 3. Москва. (in Russian)

Доблаев, Л. П. (1982). Смысловая структура учебного текста и проблемы его понимания [Semantic structure of the educational text and the problems of its understanding]. Москва: Педагогика. (in Russian)

Залевская, А. А. (2005). Психолингвистические исследования. Слово. Текст: Избранные труды [Psycholinguistic researches. Word. Text: Selected Works]. Москва: Гнозис. (in Russian)

Зимняя, И. А. (2001). Лингвопсихология речевой деятельности [Lingvopsychology of speech activity]. Москва: Московский психолого-социальный институт, Воронеж: НПО „МОДЭК”. (in Russian)

Зинченко, В. П. (2012). Понимание как философско-методологическая проблема психологи [Understanding as philosophical and methodological problem of psychology]. Методология психологии: проблемы и перспективы, 9. Под общ. ред.: В. П. Зинченко. Москва: Центр гуманитарных инициатив, С. 191-206. (in Russian)

Знаков, В.В. (1986). Основные направления исследования понимания в зарубежной психологии [Basic directions of investigation of understanding in foreign psychology]. Вопросы психологии. 3. С. 163-171.(in Russian)

Знаков, В. В. (2005). Психология понимания: Проблемы и перспективы [Psychology of understanding: Problems and Prospects]. Москва: Изд-во „Институт психологии РАH”. (in Russian)

Знаков, В. В. (2008). Мышление, самосознание и самопонимание [Thinking, self-awareness and self-understanding]. Вестник Московского университета. Серия 14 “Психология”. № 2. (апрель - июнь). С. 74-87. (in Russian)

Коваленко, А.Б. (1999). Психологія розуміння [Psychology of understanding]. К.: Геопринт. (in Ukrainian) 
Колодина, Н.И. (2001). Проблемы понимания и интерпретации художественного текста [Problems of understanding and interpretation of the literary text]. Тамбов: Изд-во ТГТУ.(in Russian)

Костюк, Г. С. (1988). О психологии понимания [On the psychology of understanding. Selected psychological works]. Избранные психологические труды. Москва: Педагогика. (in Russian)

Красных, В.В. (2012). Основы психолингвистики [Fundamentals of psycholinguistics]. М.: Гнозис. (in Russian)

Краткий словарь когнитивных терминов (1996). [Concise Dictionary of cognitive terms]. Москва: Изд-во филол. фак-та МГУ. (in Russian)

Кубрякова, Е.С. (1987). Текст - проблемы понимания интерпретации [Text - problems of interpretation understanding]. Семантика челого текста. М.: Наука. - С. 93-94. (in Russian)

Леонтьев, А. А. (1999). Основы психолингвистики [Fundamentals of psycholinguistics]. Москва: Смысл. (in Russian)

Лурия, А.Р. (2002). Письмо и речь: Нейролингвистические исследования [Writing and speaking. Neurolinguistic research ]. М.: Академия.(in Russian)

Рубакин, Н.А. (1977). Психология читателя и книги [Psychology of a reader and a book]. М.: Всесоюзн. Книжная палата. (in Russian)

Рубинштейн, С. Л. (1976). Проблемы общей психологии [Problems of general psychology]. Москва: Педагогика. (in Russian)

Румянцева, И.М. (2004). Психология речи и лингвопедагогическая психология [Psychology of speech and linvopedagogic psychology]. М.: ПЕР СЭ; Логос.(in Russian)

Селицкая, Л. А. (1976). Гносеологическая природа понимания [Epistemological nature of understanding]. Aвтореф. дис. канд. филос. наук. (in Russian)

Словник синонімів української мови [Dictionary of Ukrainian synonyms]. Retrieved 12.12.2013. from ycilka.net/slovnyk_syn. $p h p$ (in Ukrainian)

Смирнов, А. А. (1987). Проблемы психологии памяти [Problems of the psychology of memory]. Избр. психол. труды: В 2-х m. T. 2. М.: Педагогика. (in Russian)

Соколов, А.Н. (1968). Внутренняя речь и мышление [Internal speech and thinking]. Москва: Просвещение (in Russian)

Тихомиров, О.К. (1989). Мышление, знание и понимание [Thinking, knowledge and understanding]. Вестник Московского университета. Сер. 14. Психология, №2. С. 6-16. (in Russian)

Толковый словарь русского языка (2000). [Defining dictionary of Russian language]. Под ред. Д. Н. Ушакова. Москва: Гос. изд-во иностр. и нац. слов. (in Russian)

Тупицкая, А.П. (1995). Герменевтическая модель авторского понимания [Hermeneutic model of author's understanding]. Понимание менталитета и текста. Тверь: ТГУ. - C. 58-67. (in Russian)

Чепелєва, Н.В. (1990). Психологія читання тексту студентами вузів [Psychology of reading the text by higher school students]. К.: Либідь.(in Ukrainian) 